\title{
The effect of microstructure on the leaching behaviour of electric arc furnace (EAF) carbon steel slag
}

\author{
D. Mombelli ${ }^{a, *}$, C. Mapelli ${ }^{a}$, S. Barella ${ }^{a}$, C. Di Cecca ${ }^{a}$, G. Le Saout ${ }^{b}$, \\ E. Garcia-Diaz \\ a Politecnico di Milano, Dipartimento di Meccanica, Via La Masa 1, 20156 Milano, Italy \\ $\mathrm{b}$ Centre des Matériaux des Mines d'Alès (C2MA) - Ecole des Mines d'Alès (Institut Mines Telecom), Avenue de \\ Clavières 6, 30100 Alès Cedex, France
}

\begin{abstract}
A B S T R A C T
Electric arc furnace (EAF) slag could be exploited in several fields of application, such as land filling, road constructions and concrete production, since their physical properties are similar, or even better, than natural materials like gravel. Environmental concerns related to pollutants leaching ( $\mathrm{Ba}, \mathrm{V}, \mathrm{Cr}$, chlorides, fluorides, cyanides, etc.), are the primary hindrance limiting the effective reuse of such material. Thus, chemical and structural stability are fundamental requirements to be fulfilled, especially when the slag comes in contact with water. The slag microstructure has a non-negligible influence on metals concentration in leachate, even if the phases that react with water have not yet been clearly identified. In this study, different classes of carbon steel EAF slag were investigated in order to correlate their leaching behaviour with microstructural and crystallographic features. Fine particles were chosen to enhance the dissolution rate of the phases involved in the leaching process and to quantify the effects of the fine fraction on leachate concentration with respect to the bulk material. Qualitative tests at different liquid-to-solid (L/S) ratios were also performed to detect dissolution of the phases, which would otherwise be non-appreciable in standard conditions. The analyses also allowed for the identification of the phases responsible for toxic metal leaching ( $\mathrm{Ba}, \mathrm{Cr}, \mathrm{V})$, as well as those that were not involved in dissolution phenomena, thereby consolidating the results proposed elsewhere on slag stabilization.
\end{abstract}

\author{
Keywords: \\ Electric arc furnace (EAF) slag \\ Leaching behaviour \\ Microstructure \\ Fine fraction \\ Larnite \\ Gehlenite
}

\section{Introduction}

The growing interest in the use of steel slag as an alternative to traditional stone materials has prompted researchers to study in detail the chemical, physical and mechanical properties of these industrial by-products. Environmental concerns related to toxic metal leaching, are the primary hindrance limiting the effective reuse of such material, especially for slag from the electric steelmaking route. For this reason, several studies (Lind et al., 2001; Chaurand et al., 2007; van Zomeren et al., 2011; Engelsen et al., 2010, 2012) have investigated the leaching behaviour of slag aggregates, highlighting that such aggregates could potentially release dangerous chemical species (Ba, V, Cr, chlorides, fluorides, cyanides, etc.). Recently, strong correlations between leaching behaviour and the chemical composition of different classes of EAF slag have been highlighted and important considerations relating to the improvement of pollutant retaining substances were stated, concerning the standard test required by the EN 124572 regulation (Mombelli et al., 2014, 2016). Chemical composition plays a fundamental role and provides important indications on the leaching behaviour of a slag, since it determines, with cooling way, the slag microstructure (Tossavainen et al., 2007; Albertsson et al., 2013, 2014). Thus, microstructure has a non-negligible influence on metals

\footnotetext{
* Corresponding author. Tel.: +390223998660.

E-mail address: davide.mombelli@polimi.it (D. Mombelli).
} 
concentration in leachate. As a consequence, one of the most important issues to solve is the identification of the mineralogical phases responsible for the release of toxic metals. In fact, not all the slag particle surface reacts with water, but only specific phases are involved in hydration and dissolution processes (Engström et al., 2013; Mombelli et al., 2016; Strandkvist et al., 2015). Several studies (Barella et al., 2012; Mombelli et al., 2012; Gelfi et al., 2010; De Windt et al., 2011; Faellman, 2000; Engström et al., 2013; Strandkvist et al., 2015) indicate that calcium-rich crystalline phases (in particular larnite, calcium aluminate and calcium ferrite) are the most probable structural constituents involved in releasing phenomena, but which phases exactly react with water is not clearly identified. Moreover, the conditions under which the leachates are produced vary in relation to different physical parameters like granulometry, temperature or flow conditions, influencing the resulting concentrations of metals in the leachates (Faellman and Hartlén, 1996). Even if the different standard tests are carried out on bulk samples, a certain amount of fine particles is admitted, and these fine fractions negatively influence the test results, i.e. enhancing the leaching (Mizutani et al., 2006; Vítková et al., 2011; Moser and Römbke, 2009). In fact, fine particles can lead to a variation of the $\mathrm{pH}$ of the eluate and consequently to a different leachability of $\mathrm{pH}$ sensitive constituents. For this reason, the European Standards usually specify that the material should not be finely ground and plan to limit particle size reduction in order to maintain the physical state of the waste. However, no indication about the minimum admitted size and amount of fine particles is indicated in the standards. In addition, since fine particles are usually employed as filler material in cementitious components, the leaching behaviour of such manufactures could be significantly changed by the filler weight fraction. Nevertheless, since the interaction between slag and water was experimentally demonstrated to be only cortical, interesting only the particle surface, the analysis of fine particles could allow to better identify the hydration and dissolution mechanisms that rule the pollutants leaching (Mombelli et al., 2014). Effectively, the increase in the surface-to-volume (S/V) ratio of fine particles, coupled with a high liquid-to-solid (L/S) ratios, favours the identification of dissolved phases. This is because it maintains the $\mathrm{pH}$ far from basic values, thus working in conditions a long way from the saturation limit, enhancing the dissolution rate as reported by Nicoleau et al. (2013).

In this study, different classes of carbon steel EAF slag powder originating from different steel productions (reinforced bar steel, high alloyed steel and quality steel) were investigated, in order to correlate their leaching behaviour with microstructural and crystallographic features. Fine particles were chosen to enhance the dissolution rate of the phases involved in the leaching process and to quantify the effects of the fine fraction on leachate concentration with respect to the bulk material. Moreover, qualitative tests at different L/S ratios were also performed to detect the dissolution of the phases, otherwise non-appreciable in standard conditions. The main goal of the present work is to identify which crystalline phases are responsible for the toxic metal leaching $(\mathrm{Ba}, \mathrm{Cr}, \mathrm{V})$. The analyses have also allowed for the identification of the phases not involved in dissolution phenomena, thereby consolidating the results proposed elsewhere on slag stabilization by Mombelli et al. (2014; 2016). The results discussed in the present paper show quantitatively the relationship between leaching and the fraction of some mineral phases considered as key factors controlling the leaching behaviour of EAF slag.

\section{Experimental procedure}

\subsection{Material}

EAF slag were provided by different Italian and European electric steelworks and associated to different steel productions: reinforcing bar steel (group A, 7 samples), high-alloyed steel (group B, 4 samples) and quality steels (group C, 4 samples).

The investigated samples represent a selected subset from a larger sampling, previously analyzed by the same authors (Mombelli et al., 2016).

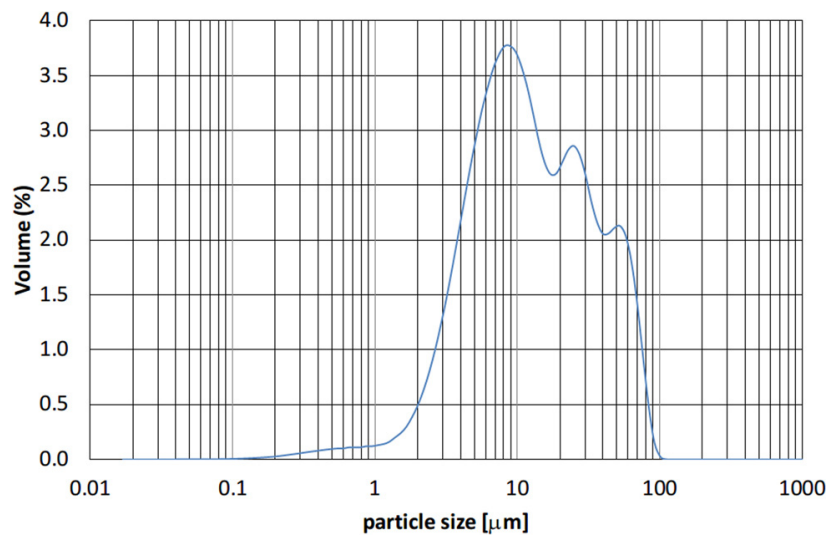

Fig. 1 - Particle size distribution of investigated slag powder.

The slag chemical composition was provided by ED-XRF analysis by means of Ametec Spectro Xepos spectrometer in He atmosphere on $5 \mathrm{~g}$ of powdered slag (Table 1).

The samples, in the form of powder obtained by ring mill grinding (particle size distribution in Fig. 1), were morphological and microstructural characterized by means of XRD and SEM analysis, and leaching tests were carried out in deionized water at $\mathrm{pH}$ 7, varying the liquid-to-solid ratio. To determine which phases were responsible for metals release, leaching tests on the polished section were also performed. Leaching tests results were correlated to chemical composition and crystalline phase fraction.

\subsection{Crystallographic and microstructural characterizations}

X-ray diffraction (XRD) data was collected using a Bruker D8 Advance diffractometer in a $\theta-\theta$ configuration employing the $\mathrm{Cu} \mathrm{K} \alpha$ radiation $(\lambda=1.54 \AA$ ) with a fixed divergence slit size $0.5^{\circ}$ and a rotating sample stage. The samples were scanned between $10^{\circ}$ and $80^{\circ}$ (step size of $0.007^{\circ}$ ) with the Vantec detector. The qualitative analysis was performed with EVA software whereas a semi-quantitative analysis was performed by Crystal Match! Software, exploiting the Reference Intensity Ratio method (RiR-method) (de Wolff and Visser, 1988), calibrating the results on the base of a experimentally determined larnite fraction. Larnite fraction was determined through a selective dissolution in methanol-salicylic acid solution (Klemm and Skalny, 1977). $2.5 \mathrm{~g}$ of slag powder was mixed in $150 \mathrm{ml}$ of methanol acidified with $10 \mathrm{~g}$ of salicylic acid. The solution was stirred for $2 \mathrm{~h}$ at $100 \mathrm{rpm}$ and decanted for $15 \mathrm{~min}$ before filtering in a $0.45 \mu \mathrm{m}$ vacuum system. The residual slag powder was dried at $105^{\circ} \mathrm{C}$ for $1 \mathrm{~h}$ and weighed again (balance accuracy: $0.0001 \mathrm{~g}$ ). The weight difference is a good estimation of larnite fraction.

Morphological and microstructural characterization was performed by Zeiss EVO50 Scanning Electron Microscopy (SEM) equipped with an Oxford Inca EDS probe. Slags were moulded in araldite-based resin, ground and polished.

\subsection{Leaching test}

Slag powder leaching behaviour was investigated by varying the $\mathrm{L} / \mathrm{S}$ ratio $(10,100,1000 \mathrm{l} / \mathrm{kg})$. Weight loss, water $\mathrm{pH}$ and conductivity were measured after each test and the dried powders were investigated by XRD. The test consisted in immersing the slag powder in deionized water for 1 day, 
Table 1 - Chemical composition range (min-max) of the investigated slag (wt.\%).

\begin{tabular}{llccccccc} 
Group ID & $\mathrm{MgO}$ & $\mathrm{Al}_{2} \mathrm{O}_{3}$ & $\mathrm{SiO}_{2}$ & $\mathrm{CaO}$ & $\mathrm{FeOx}$ & $\mathrm{Cr}_{2} \mathrm{O}_{3}$ & $\mathrm{~V}_{2} \mathrm{O}_{5}$ & $\mathrm{Ba}$ \\
\hline $\mathrm{A}$ & $2-5$ & $10-15$ & $15-20$ & $15-25$ & $30-50$ & $2-5$ & $0.1-0.2$ & $0.05-0.1$ \\
$\mathrm{~B}$ & $1-3$ & $1-3$ & $5-25$ & $15-25$ & $30-50$ & $5-30$ & $1-2$ & n.d. \\
C & $5-15$ & $5-15$ & $10-40$ & $20-50$ & $5-30$ & $0.5-5$ & $0.05-0.4$ & $0.1-0.5$ \\
\hline
\end{tabular}

Table 2 - XRD semi-quantitative analysis (wt.\%). $\mathrm{L}_{\mathrm{m}}$ indicated the larnite fraction measured by selective dissolution technique.

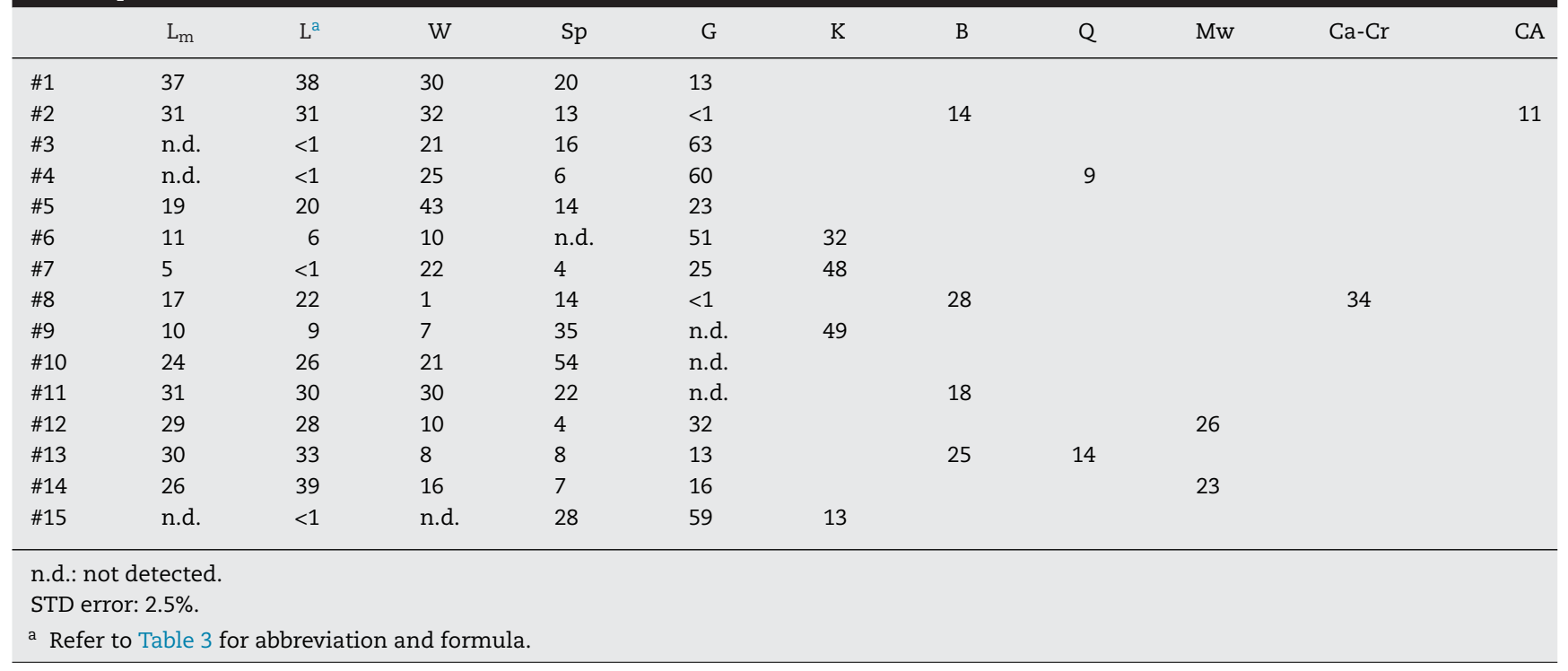

keep shacked the PTFE bottle as recommended by EN 12457-2 standard. After $24 \mathrm{~h}$, slags were removed and the water solution was filtered by $0.45 \mu \mathrm{m}$ vacuum system and analyzed with a spectroscopic technique, i.e. ICP-OES (Induced Coupled Plasma-Optical Emission Spectroscopy, detection limit $50 \mu \mathrm{g} / \mathrm{l})$. The analysis focused on $\mathrm{Al}, \mathrm{Ba}, \mathrm{Ca}, \mathrm{Cr}, \mathrm{Mg}$ and $\mathrm{V}$. In addition, the polished section of massive grains were leached in the same conditions as before and followed by a SEM investigation in order to detect which phases were dissolved or resist at a very high $\mathrm{L} / \mathrm{S}$ ratio.

\section{Results and discussion}

\subsection{Crystallographic and microstructural characterizations}

In Table 2 the crystalline phases fraction is reported. The larnite percentage obtained by selective dissolution is also indicated. The XRD semi-quantitative analysis can be considered reliable since the difference between measured and calculated larnite fraction is negligible and at most less than $5 \%$. Only sample \#14, shows a large difference between calculated and measured larnite fraction. This could be due to the high sample heterogeneity.

In nearly every case the crystallographic analysis highlighted the occurrence of four phases ${ }^{1}$ (Tossavainen et al., 2007; Shen et al., 2004; Shi, 2004; Luxan et al., 2000; Tsakiridis et al., 2008; Juckes, 2003; Reddy et al., 2006; Nicolae et al., 2007; Qian et al., 2002a,b; Manso et al., 2005; Geiseler, 1996; Wachsmuth et al., 1981): larnite, wustite, (Mg,Al,Fe,Cr) spinels, and gehlenite. Other phases, like brownmillerite, kirschsteinite or merwinite, were detected in specific samples, i.e.

\footnotetext{
${ }^{1}$ Refer to Table 3 for abbreviation and formula.
}

samples \#2, 8, 12 and 14. Only sample \#8 was characterized by Ca-chromite, that appears as elongated lamellae (Fig. 2) inducing an intense diffraction peak at 20:16 (Cabrera-Real et al., 2012; Albertsson et al., 2014).

By SEM-EDS analysis, the mapping of the toxic element $(\mathrm{Ba}, \mathrm{V}, \mathrm{Cr}$ ) and their content in the different crystalline phases was reported (Table 3). The data show that $\mathrm{Ba}$ tends to dissolve mainly in calcium silicates (larnite, bredigite - from 0.5 up to 6 at.\%) and in calcium aluminates (mayenite and brownmillerite $-0.5-40$ at.\%). V is mainly associated to brownmillerite (up to 1 at.\%), larnite (approximately 1 at.\%) and spinel (1.1 at.\%), even significant amount can be detected also in wustite. $\mathrm{Cr}$ is mainly associated to spinel (30-50 at.\%) and Ca-chromite (c.a. 50 at.\%), and to a lesser extent to wustite ( $\max 3$ at.\%) and brownmillerite ( $\max 9$ at.\%). Traces of $\mathrm{Cr}$ can be also found in calcium silicates, especially larnite. In disagreement with the literature (Durink, 2008; Albertsson et al., 2013), Cr was detected neither in merwinite nor in akermanitegehlenite.

Four main phases characterize almost all of the entire group of analyzed slag; the effects of such phases on leaching behaviour of fine particles will be discussed in the text. In particular, the influence of larnite, gehlenite and spinels is discussed. As documented by Belhadj et al. (2012) wustite is considered completely nonreactive, however.

\subsection{Leaching test at $10 \mathrm{l} / \mathrm{kg}$}

First of all, to highlight the important effect of fine particles on leaching test, the comparison between leaching results in standard conditions ( $24 \mathrm{~h}$ mixing, L/S $=10 \mathrm{l} / \mathrm{kg}$, deionized water $\mathrm{pH} 7$ ) of powder and bulk samples was carried out. The bulk behaviour was reported by Mombelli et al. (2016).

The comparison highlighted the significant effect of particle size on dangerous metal concentration in the leachate 
CA
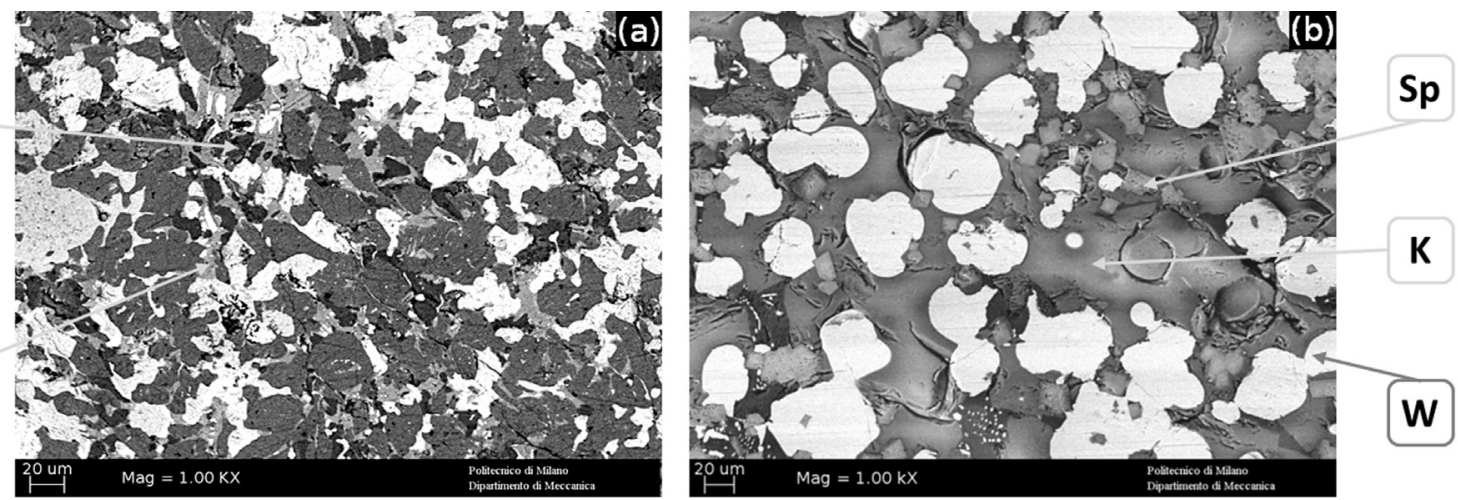

B
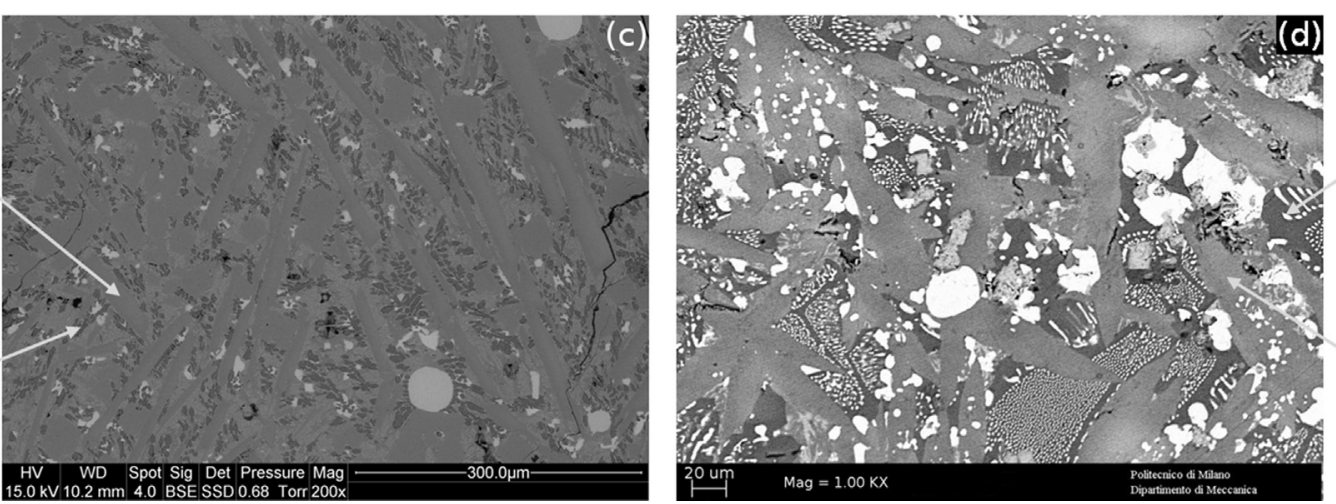

G

\section{$\mathrm{Ca}-\mathrm{Cr}$}

$\mathbf{L}$

Fig. 2 - Examples of microstructure: (a) sample \#2; (b) sample \#7; (c) sample \#8 and (d) sample \#12. Refer to Table 3 for abbreviations and formula.

\begin{tabular}{|c|c|c|c|c|c|c|}
\hline Phase & Symbol & Definition & Formula & $\mathrm{Ba}$ & $\mathrm{V}$ & $\mathrm{Cr}$ \\
\hline Bredigite & $\mathrm{Br}$ & $\alpha$ di-calcium silicate & $\begin{array}{l}\mathrm{Ca}_{7} \mathrm{Mg}\left(\mathrm{SiO}_{4}\right)_{4} \\
\left(7 \mathrm{CaO} \cdot \mathrm{MgO} \cdot 4 \mathrm{SiO}_{2}\right)\end{array}$ & $0.15-0.60$ & $0.10-0.15$ & $0.00-0.15$ \\
\hline Brownmillerite & B & $\begin{array}{l}\text { Tetra-calcium } \\
\text { aluminate ferrite }\end{array}$ & $\begin{array}{l}\mathrm{Ca}_{2}(\mathrm{Al}, \mathrm{Fe})_{2} \mathrm{O}_{5} \\
\left(4 \mathrm{CaO} \cdot \mathrm{Al}_{2} \mathrm{O}_{3} \cdot \mathrm{Fe}_{2} \mathrm{O}_{3}\right)\end{array}$ & $0.15-0.40$ & $0.5-1.0$ & $1.0-10.0$ \\
\hline Ca-chromite & $\mathrm{Ca}-\mathrm{Cr}$ & Calcium chromite & $\begin{array}{l}\mathrm{CaCr}_{2} \mathrm{O} 4 \\
\left(\mathrm{CaO}^{-} \mathrm{Cr}_{2} \mathrm{O}_{3}\right)\end{array}$ & - & - & $45.0-55.0$ \\
\hline Gehlenite-akermanite & G & Ca-Mg-Al silicate & $\begin{array}{l}\mathrm{Ca}_{2} \mathrm{Al}(\mathrm{AlSi}) \mathrm{O}_{7}-\mathrm{Ca}_{2} \mathrm{MgSi}_{2} \mathrm{O}_{7} \\
\left(2 \mathrm{CaO} \cdot \mathrm{Al}_{2} \mathrm{O}_{3} \cdot \mathrm{SiO}_{2}-\right. \\
\left.2 \mathrm{CaO} \cdot \mathrm{MgO}_{2} \mathrm{SiO}_{2}\right)\end{array}$ & $0.07-0.15$ & $0.08-0.15$ & $0.00-0.04$ \\
\hline Kirschsteinite & $\mathrm{K}$ & Calcium olivine & $\begin{array}{l}\mathrm{CaFeSiO}_{4} \\
\left(\mathrm{CaO} \cdot \mathrm{FeO} \cdot \mathrm{SiO}_{2}\right)\end{array}$ & $0.02-0.06$ & $0.05-0.30$ & $0.03-0.50$ \\
\hline Larnite & $\mathrm{L}$ & $\begin{array}{l}\beta \text { or } \gamma \text { di-calcium } \\
\text { silicate }\end{array}$ & $\begin{array}{l}\mathrm{Ca}_{2} \mathrm{SiO}_{4} \\
\left(2 \mathrm{CaO} \cdot \mathrm{SiO}_{2}\right)\end{array}$ & $0.05-0.30$ & $0.10-0.90$ & $0.2-1.3$ \\
\hline Mayenite & $\mathrm{CA}$ & Calcium aluminate & $\begin{array}{l}\mathrm{Ca}_{12} \mathrm{Al}_{14} \mathrm{O}_{33} \\
\left(12 \mathrm{CaO} \cdot 7 \mathrm{Al}_{2} \mathrm{O}_{3}\right)\end{array}$ & $0.05-0.40$ & $0.01-0.20$ & $0.1-0.10$ \\
\hline Merwinite & $\mathrm{Mw}$ & Ca-Mg silicate & $\begin{array}{l}\mathrm{Ca}_{3} \mathrm{Mg}\left(\mathrm{SiO}_{4}\right)_{2} \\
\left(3 \mathrm{CaO} \cdot \mathrm{MgO}_{2} \mathrm{SiO}_{2}\right)\end{array}$ & $0.10-0.15$ & $0.05-0.10$ & - \\
\hline Mg-Cr-spinel & $\mathrm{Sp}$ & $\begin{array}{l}\text { Magnesiochromite } \\
\text { (spinel) }\end{array}$ & $\begin{array}{l}\mathrm{MgCr}_{2} \mathrm{O}_{4} / \\
(\mathrm{Mg}, \mathrm{Fe})(\mathrm{Al}, \mathrm{Cr})_{2} \mathrm{O}_{4}\end{array}$ & $0.05-0.10$ & $0.10-1.10$ & $31.0-55.0$ \\
\hline Wustite & W & Iron oxide & $\begin{array}{l}(\mathrm{Fe}, \mathrm{Mg}, \mathrm{Mn}) \mathrm{O} / \\
\mathrm{MgO}-\mathrm{FeO}\end{array}$ & $0.02-0.10$ & $0.05-0.70$ & $0.5-3.0$ \\
\hline
\end{tabular}

(Fig. 3). As expected, the high surface-on-volume ratio of the fine slag particles induced a higher release of $\mathrm{Ba}$ and $\mathrm{V}$ than that obtained performing the bulk test. In fact, with respect to the bulk slag, leached Ba was 3 times higher (Fig. 3a) and leached $\mathrm{V}$ was about twice as high for the fine particle samples (Fig. 3b). On the contrary, $\mathrm{Cr}$ leaching showed an opposite trend, since the highest $\mathrm{Cr}$ concentrations were produced by samples with very low $\mathrm{Cr}$ leaching during the standard test on $4 \mathrm{~mm}$ particles (Fig. 3c). Contrary to what was expected, the leachate $\mathrm{pH}$ was almost the same for powder and bulk slag (Fig. 3d). Only for some samples the powder slag induced a pH $5-10 \%$ higher than the respective bulk sample. This result emphasizes that the high S/V ratio of the fine particles favours a greater release of $\mathrm{Ba}$ and $\mathrm{V}$ and a concomitant reduction of $\mathrm{Cr}$ if compared with the marginal effect of the reduction of size on the final leachate $\mathrm{pH}$.

These results provide a preliminary indication about the risk associated to the presence of fine particles during the production of aggregates, since the leaching behaviour could change extremely by the volume fraction of such fine powders. Nevertheless, the mass loss registered in both cases was negligible, hardly overcoming the $1 \mathrm{wt} . \%$. This again underlines the limited interaction between slag and water and the primary role of the distribution of the phases within the slag. 

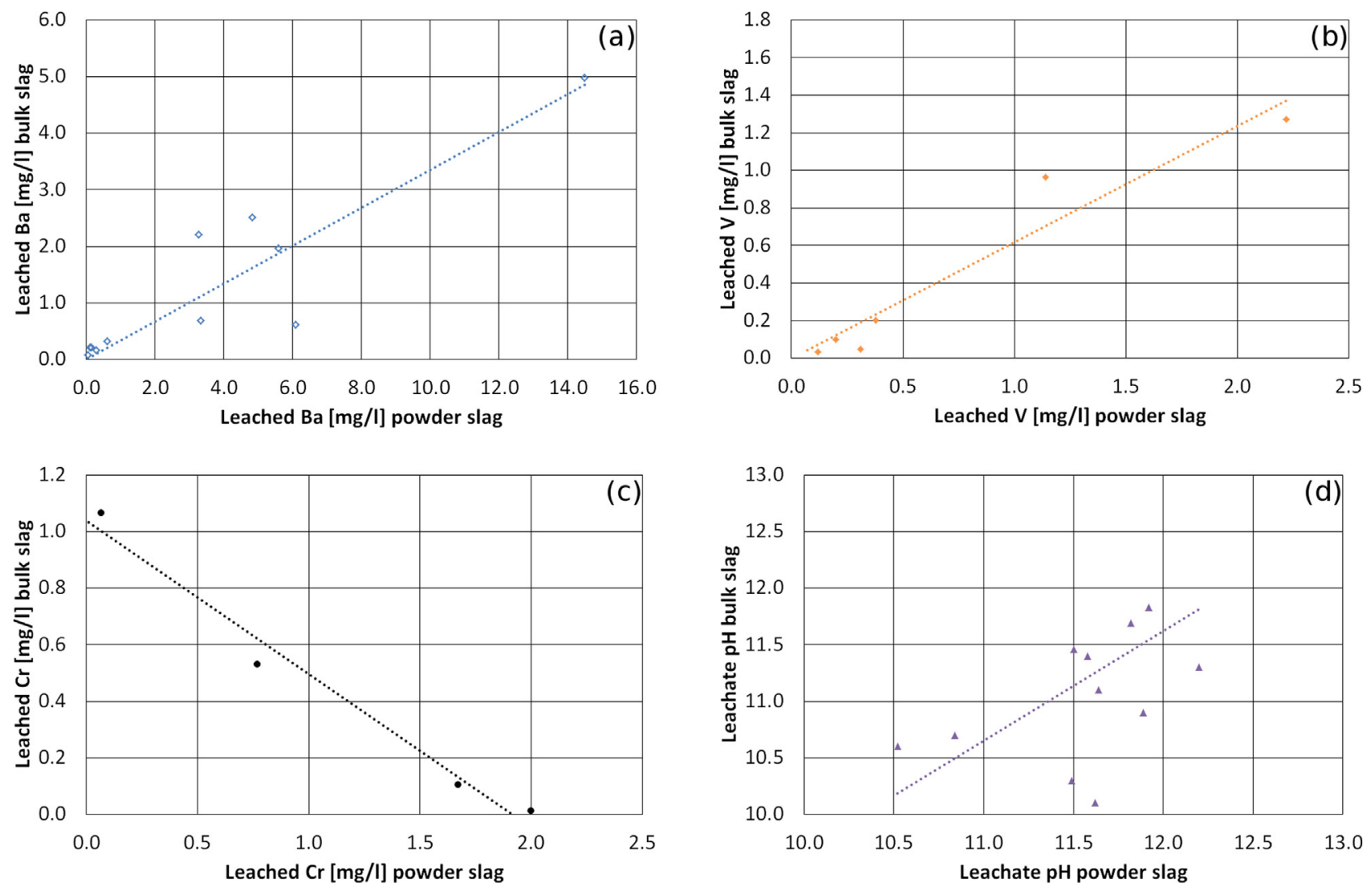

Fig. 3 - Comparison between element leaching from powder and bulk slag: (a) Ba, (b) V, (c) $\mathrm{Cr}$ and (d) $\mathrm{pH}$.

Leaching tests on the slag powder confirmed the $\mathrm{Ba}-\mathrm{V}$ leaching behaviour described by the same authors (Mombelli et al., 2016). When barium is detected, vanadium concentration is always under the ICP-OES detectable limit $(50 \mu \mathrm{g} / \mathrm{l})$.

Different relations in leachate concentration can be highlighted: $\mathrm{Ba}$ is directly proportional with $\mathrm{Ca}$ and $\mathrm{Al}$ dissolved in the eluate; inverse logarithmic dependence was identified between leached $\mathrm{Mg}$ and Ba (Fig. 4a). Dissolved calcium could derive from the dissolution of larnite, or other hydraulic silicates, as well as from brownmillerite or other Ca-rich compounds (mayenite). A study conducted by Engström et al. (2013) on pure slag minerals, confirms the attitude of larnite, mayenite and calcium aluminate to dissolve rapidly at all the investigated $\mathrm{pH}$. Aluminium could be associated to calcium-aluminates, brownmillerite or spinels dissolution. In particular, the concentration of the above mentioned elements are not stoichiometric with respect to their concentration in the associated phases, thus complicating the identification of the involved phases. In fact, during the leaching of silicate-like material, the incongruent dissolution phenomenon generally occurs. This phenomenon, which was widely documented in the natural weathering process of silicate minerals by Ruiz-Agudo et al. (2012), leads to the formation of a Ca-depleted solid layer during leaching (Huijgen et al., 2006), in which the composition influences the dissolution/precipitation mechanisms, indicating nonstoichiometric release of solid phase constituents into the liquid phase.

However, the barium release seems to be effectively ruled by larnite, brownmillerite and mayenite dissolution, since these three mineralogical phases have hydraulic properties and good affinity with water (Lea, 1970; Taylor, 1990; Hewlett, 1998; Bensted, 2002; Gartner et al., 2002; Raab et al., 2008).
During hydration, brownmillerite forms $4 \mathrm{CaO} \cdot \mathrm{Al}_{2} \mathrm{O}_{3} \cdot n \mathrm{H}_{2} \mathrm{O}$ and hydrated iron oxide gel (Hewlett, 1998; Taylor, 1990). This is a fast and exothermic reaction, but precipitation of an insoluble layer of hydrated iron oxide on the calcium aluminoferrite crystal surface forms a barrier to further reactions. For this reason the role of brownmillerite could be only marginal, even if the direct proportion between $\mathrm{Ca}$ and $\mathrm{Al}$ (Fig. 4b) seems to confirm the contribution of brownmillerite and mayenite to the leaching process.

$\mathrm{Mg}$ and Ba belong to the same chemical group and that can explain the detected reciprocal behaviour. Ba leaching seems to be favoured when $\mathrm{Mg}$ is well bound in non-hydraulic phases (i.e. wustite), whereas $\mathrm{Ba}$ leaching is limited when $\mathrm{Mg}$ might be released, and this is due to its implication in hydration phenomena. In addition, the solubility of $\mathrm{Mg}$ influences the solubility of $\mathrm{Ba}$. For example, when the $\mathrm{Mg}$ concentration is high, the media is no longer been able to dissolve $\mathrm{Ba}$. The same behaviour is presented between $\mathrm{Ca}$ and $\mathrm{Mg}$ (Fig. 4b).

Vanadium leaching was associated to $\mathrm{Cr}$ leaching by linear relation, highlighting the mutual controlling behaviour of such species. Mg-V presents the same behaviour shown by $\mathrm{Mg}-\mathrm{Ba}$ (Fig. 4c).

High leaching of $\mathrm{Al}, \mathrm{Ba}, \mathrm{Ca}, \mathrm{Cr}$ and $\mathrm{V}$ was associated to high leachate $\mathrm{pH}$, as indicated in Fig. $5 \mathrm{a}-\mathrm{c}$, whereas high $\mathrm{Mg}$ leaching were found in less caustic solutions (Fig. 5a). High concentrations of alkaline elements rapidly rise up the $\mathrm{pH}$ of a solution. In addition, high concentrations of $\mathrm{Ca}$ and $\mathrm{Ba}$ in the leachate could inhibit the dissolution of $\mathrm{Mg}$, since its solubility is inversely proportional to other alkali concentrations. $\mathrm{V}$ and $\mathrm{Cr}$ behave as anions, and should be highly dissolved in basic $\mathrm{pH}$, as reported in U-Mate report (U-Mate, 2012). The leachate conductivity shows the same trend of $\mathrm{pH}$ as a function of the main elements investigated ( $\mathrm{Al}, \mathrm{Ba}, \mathrm{Ca}$ and $\mathrm{Mg}$ ), since high 
- $\mathrm{Mg} \sim \mathrm{Ca} \triangle \mathrm{Al}$

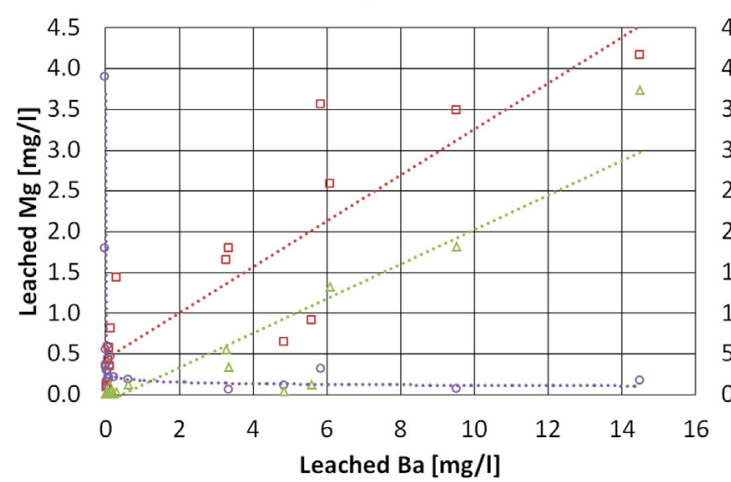

$\triangle \mathrm{Al} \circ \mathrm{Mg}$

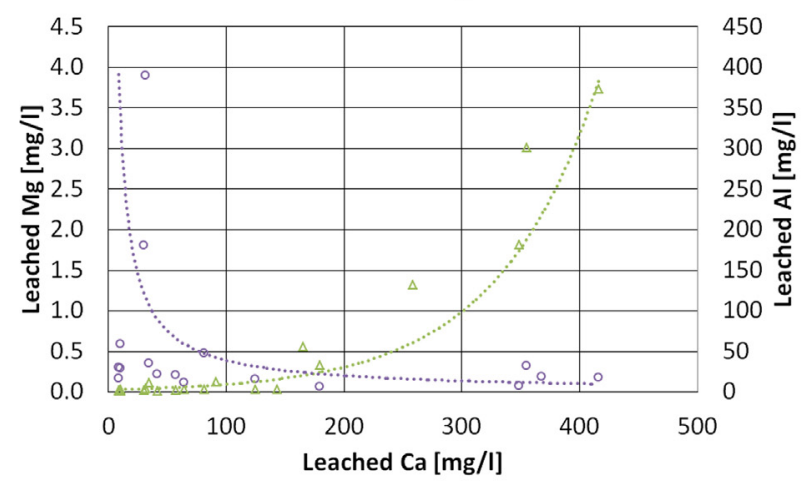

$\circ \mathrm{Mg} \cdot \mathrm{Cr}$

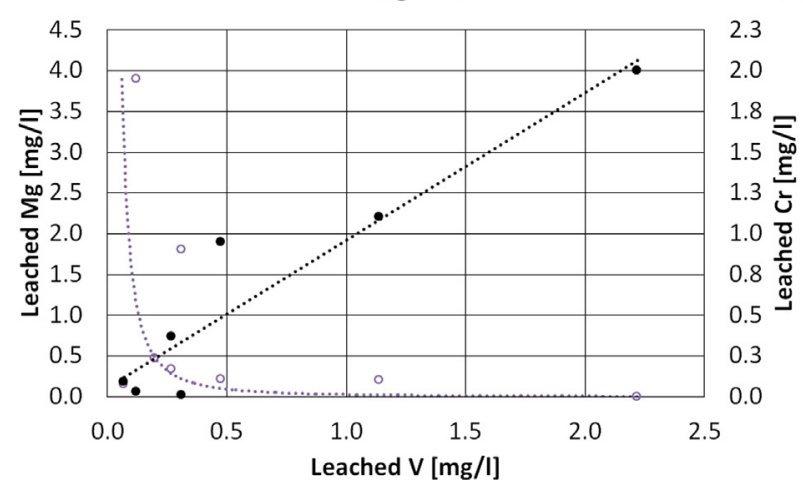

Fig. 4 - Interaction among leached substances: Ba vs $\mathrm{Mg}$, $\mathrm{Ca}$ and $\mathrm{Al}$ (a); $\mathrm{Ca}$ vs $\mathrm{Al}$ and $\mathrm{Mg}$ (b); $\mathrm{V}$ vs $\mathrm{Mg}$ and $\mathrm{Cr}$ (c). (a)

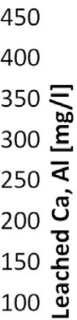

50

(b)

$300 \stackrel{\overline{0}}{\mathrm{\varepsilon}}$

$250 \frac{2}{8}$

200 율

$100 \stackrel{๑}{\unlhd}$

(c)

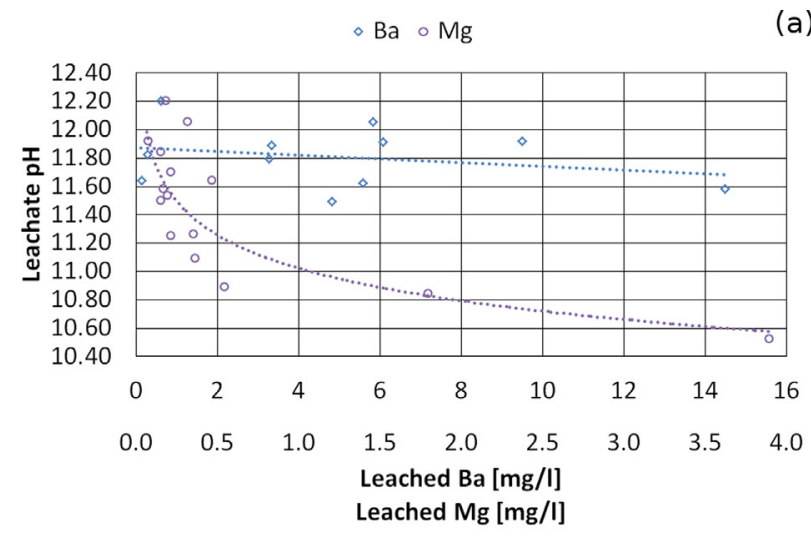

$\square \mathrm{Ca} \triangle \mathrm{Al}$

(b)

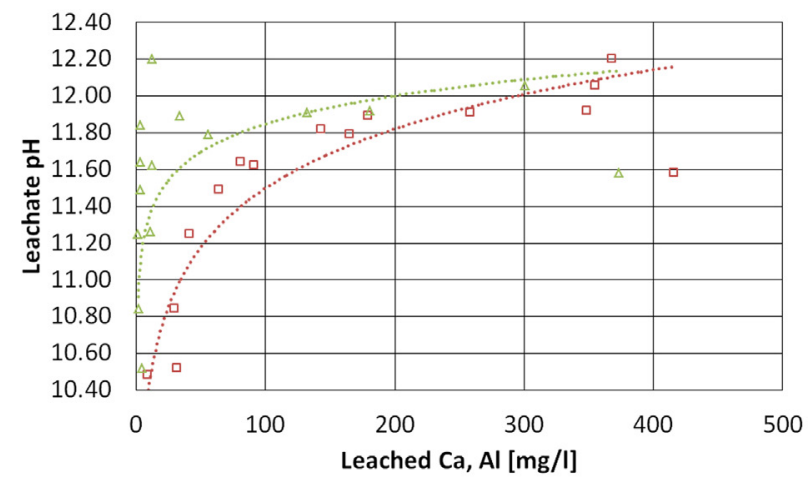

$\cdot \mathrm{V} \cdot \mathrm{Cr}$

(c)

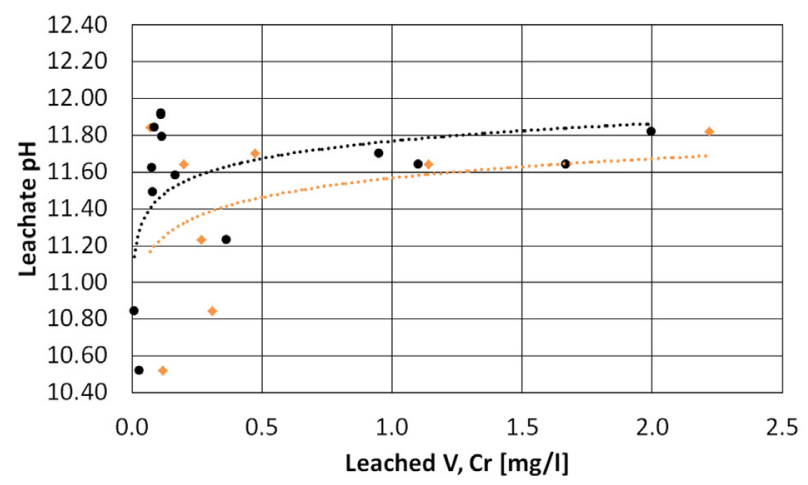

Fig. 5 - Effect of leached substances on leachate $\mathrm{pH}$ : $\mathrm{Ba}$ and $\mathrm{Mg}$ (a); $\mathrm{Ca}$ and $\mathrm{Al}$ (b); $\mathrm{V}$ and $\mathrm{Cr}$ (c).

- Ba $\circ \mathrm{Mg}$

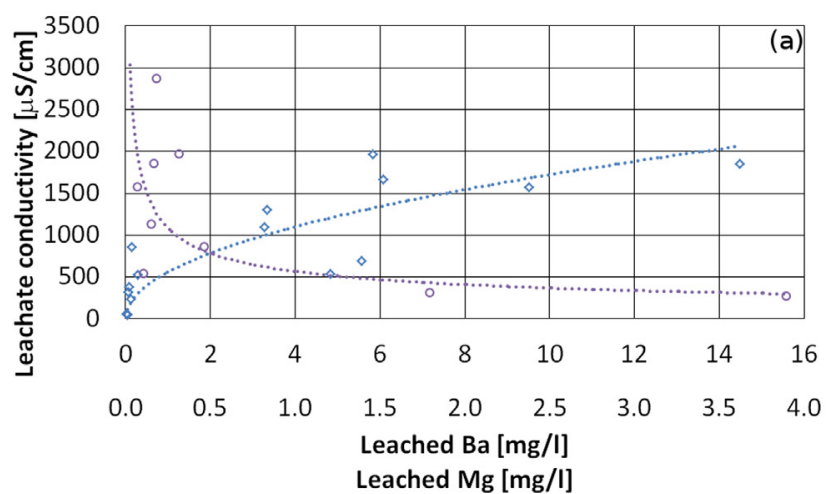

- $\mathrm{Ca} \triangle \mathrm{Al}$

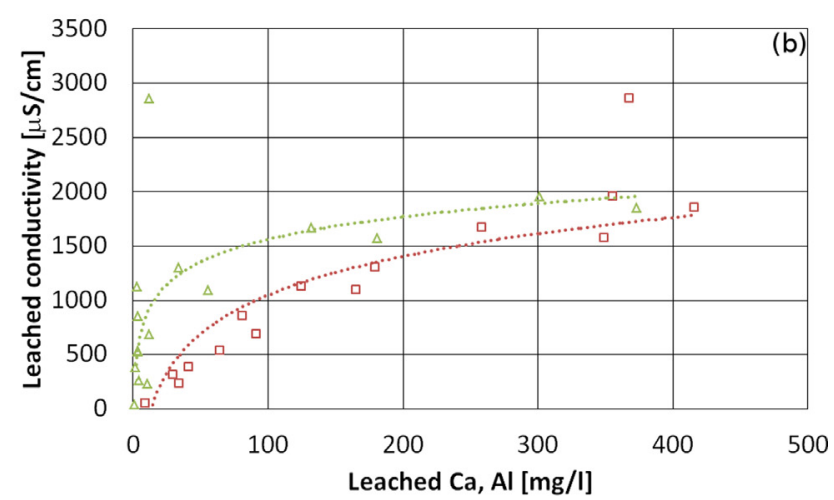

Fig. 6 - Effect of leached substances on leachate conductivity: $\mathrm{Ba}$ and $\mathrm{Mg}$ (a); $\mathrm{Ca}$ and $\mathrm{Al}$ (b). 
ions concentration in a solution lead to an increase of electrical conductivity (Fig. 6a and b). No correlation amongst Cr, V and conductivity were found.

\subsection{Effects of microstructure on leaching in standard conditions}

Correlation between elution test results and crystallographic analysis allows to better determine the potential phases responsible for the elements being released.

A logarithmic trend was identified between larnite fraction and the leachate $\mathrm{pH}$ (Fig. 7a). This relation seems to validate the hypothesis about the key role played by larnite in slag leaching behaviour: larnite fraction controls the most of $\mathrm{Ca}$ concentration in the leachate (Fig. 7b) and it also determines the final water $\mathrm{pH}$. The higher the larnite fraction in the slag, the higher the ion concentration ( $\mathrm{Al}, \mathrm{Ca}$ and $\mathrm{Ba}$ ) in the leachate. This is confirmed by the direct proportion between larnite fraction and leachate conductivity (Fig. 7a). Even if $\mathrm{Al}$ is not an element-forming of larnite, the occurrence of incongruent dissolution can explain why Al leaching is high in high larnite fraction slag.

$\mathrm{Mg}$ dissolution manifests an opposite trend as the larnite fraction increases. This result confirms the role of larnite in $\mathrm{Ba}$ leaching and the observed trend can be explained on the basis of the hydration chemistry of dicalcium silicate, discussed in the previous paragraph.

Slag characterized by a high gehlenite fraction signal a significant reduction in calcium, aluminium and barium elution (Fig. 7d). High gehlenite fraction could induce modestly high $\mathrm{Mg}$ leaching and prevent the $\mathrm{Ba}$ leaching. The dissolution of $\mathrm{BaO}$ into the gehlenite reduces the solubility of $\mathrm{MgO}$ in the same phase. In addition, the amount of $\mathrm{Ba}$ and $\mathrm{V}$ trapped in gehlenite (Table 3) is not leached, since this phase has been proved to own extremely low solubility in water solution, especially at high pH (Engström et al., 2013). If the slag is poor in chemical species that can bind $\mathrm{MgO}, \mathrm{Mg}$ leaching can be enhanced. In fact, high Mg elution is associated to low Mg-Crspinels fraction (Fig. 8a), as well as Al leaching.

The spinel fraction seems to control the leaching of $\mathrm{V}$ and $\mathrm{Cr}$ (Fig. 8b). For instance, the higher the spinel fraction, the higher the $\mathrm{V}$ and $\mathrm{Cr}$ leaching is. High spinel fraction is generally associated to the slag belonging to group $\mathrm{B}$, hence characterized by high $\mathrm{Cr}_{2} \mathrm{O}_{3}$ content (5-30wt.\%). In fact, as reported by Liao et al. (2016), the $\mathrm{Cr}$ incorporation in the spinel phase depends upon its initial concentration in the slag. Higher the available $\mathrm{Cr}$, higher the amount of $\mathrm{Cr}$ incorporated in the spinel is. Moreover, the $\mathrm{B}$-group slag are generally characterized by a low amount of $\mathrm{MgO}$ and $\mathrm{Al}_{2} \mathrm{O}_{3}$ (Table 2) and thus, the spinels tend to be over-saturated in $\mathrm{Cr}$. Attempting to evaluate the spinel stability of such slag thorough the use of sp-factor (Eq. (1)) (Kühn et al., 2006; Mudersbach et al., 2009), the excess of $\mathrm{Cr}_{2} \mathrm{O}_{3}$ and the low amount of $\mathrm{MgO}$ and $\mathrm{Al}_{2} \mathrm{O}_{3}$ play against the formation of stable spinels.

$$
\begin{aligned}
\text { sp-factor } & =0.2 \cdot \mathrm{MgO}+1.0 \cdot \mathrm{Al}_{2} \mathrm{O}_{3}+n \cdot \mathrm{FeO}_{n} \\
& \left.-0.5 \cdot \mathrm{Cr}_{2} \mathrm{O}_{3} \quad \text { (wt. } \%\right)
\end{aligned}
$$

where $n$ is the optical electronegativity of iron ions, depends on the oxidation state of the EAF-slag and can assume a value of between 1 and 4 as a function of the oxidation number assumed by the Fe ions.

Furthermore, it seems that the higher the spinel fraction, the higher the probability is to form unstable spinel. This hypothesis seems confirmed by the analysis reported in Fig. 9, related to three different samples, one belonging to group $\mathrm{A}$ $\circ \mathrm{pH} \quad$ a conductivity

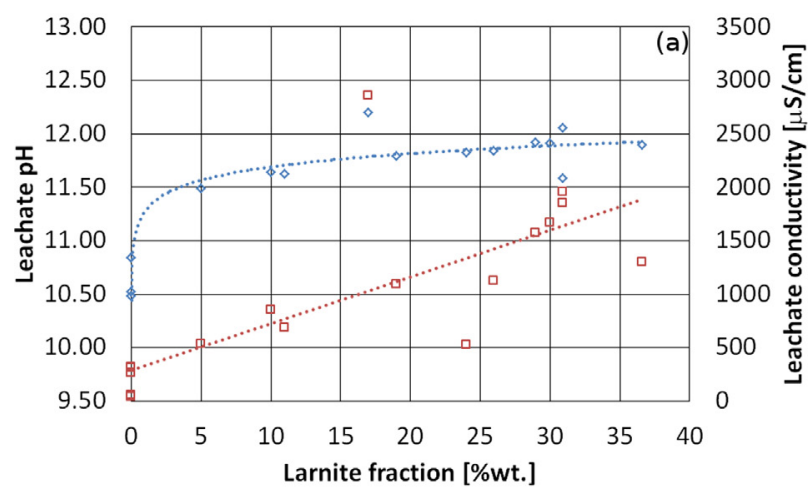

$\bullet \mathrm{pH} \quad \square$ conductivity

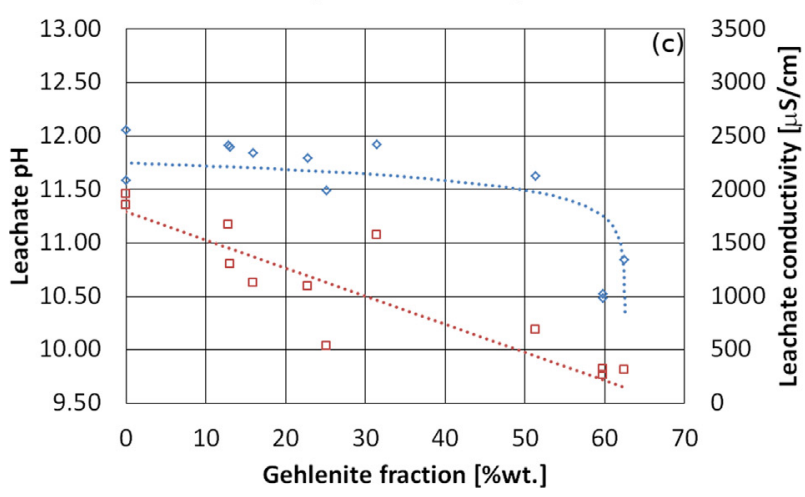

$\diamond \mathrm{Ba} \circ \mathrm{Mg} \sim \mathrm{Ca} \triangle \mathrm{Al}$

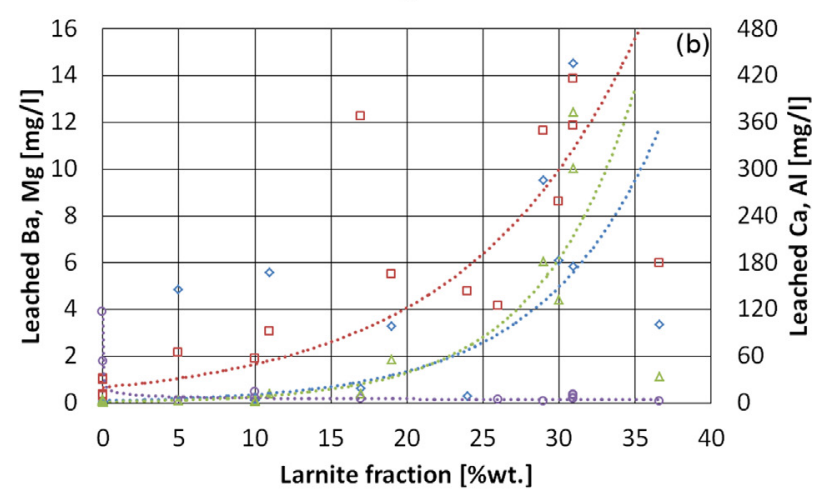

$\diamond \mathrm{Ba} \circ \mathrm{Mg} \square \mathrm{Ca} \triangle \mathrm{Al}$

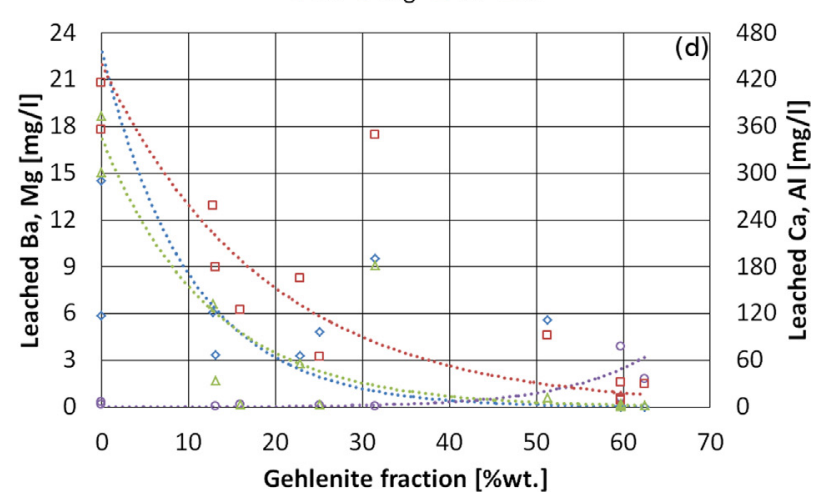

Fig. 7 - Effect of larnite (a, b) and gehlenite (c, d) weight fraction on leached $\mathrm{Al}, \mathrm{Ba}, \mathrm{Ca}, \mathrm{Mg}$, $\mathrm{pH}$ and conductivity. 

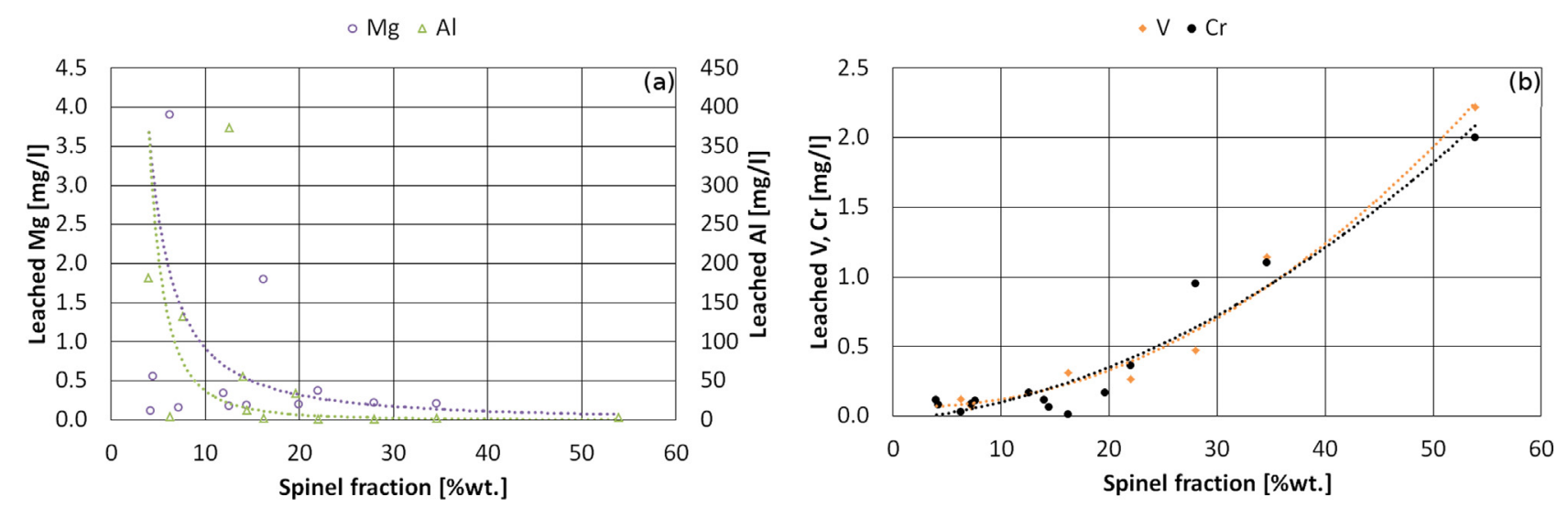

Fig. 8 - Effect of spinel weight fraction on $\mathrm{Mg}, \mathrm{Al}(\mathrm{a})$ and $\mathrm{V}, \mathrm{Cr}(\mathrm{b})$ leaching.

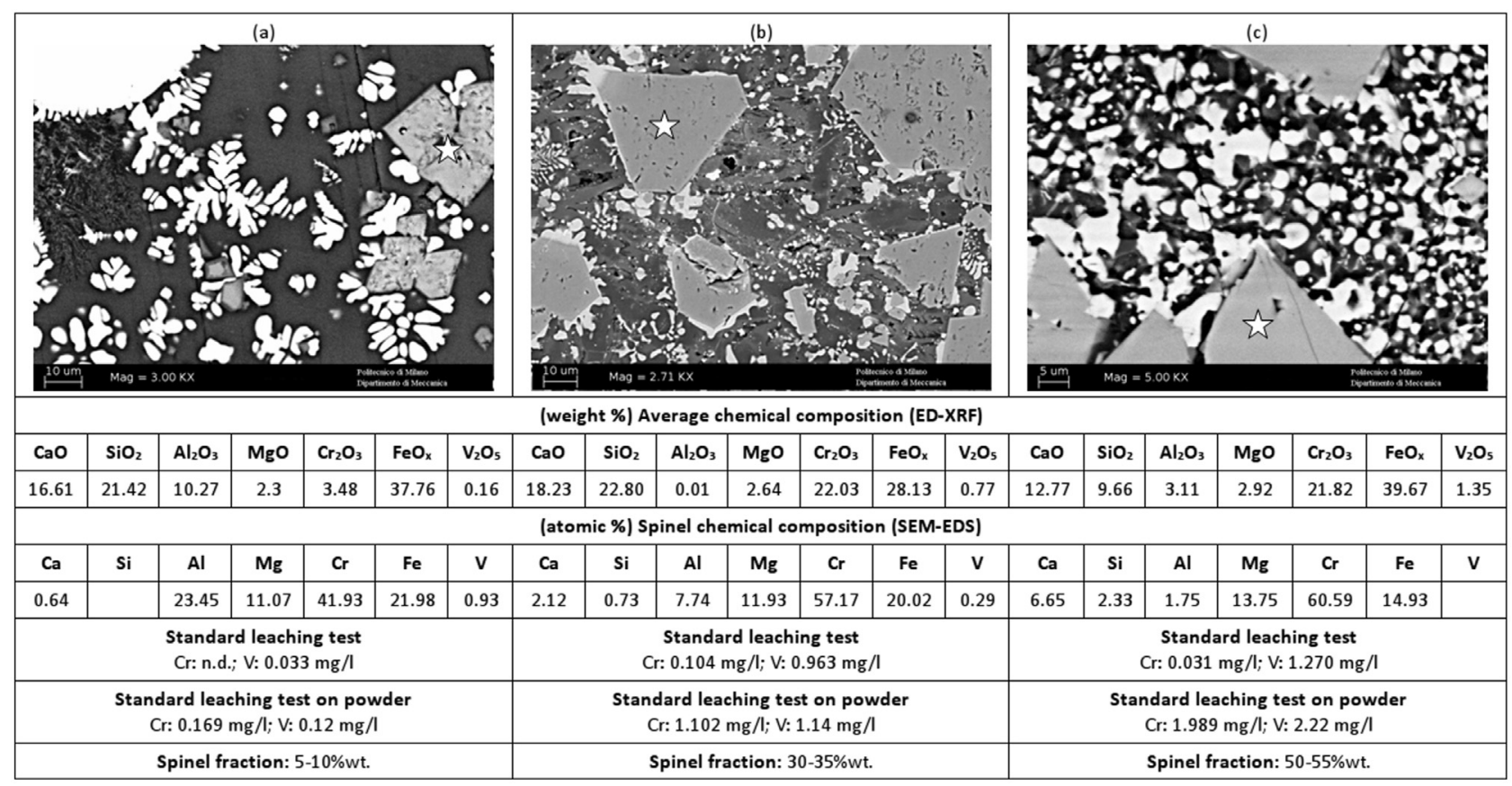

Fig. 9 - Comparison between the spinel formed in three different slags belonging to (a) group A (sample A) and (b, c) group B (samples B1 and B2).

(Fig. 9a) and two belonging to group B (Fig. 9b and c). Specifically, increasing the binary basicity index $\left(\mathrm{CaO} / \mathrm{SiO}_{2}\right)$, the impurities content ( $\mathrm{Ca}$ and $\mathrm{Si}$ ) in the spinel increases, too. In addition, as pointed out by SEM-EDS analysis, the $\mathrm{Al}_{2} \mathrm{O}_{3}$ concentration in the spinel differs from sample A to samples $\mathrm{B} 1$ and B2. For example, in sample A, 23.45 at.\% of Al was detected in the spinel phase instead to 1.75 at.\% of sample B2. Also the $\mathrm{V}$ dissolved in the spinel phase is higher in the sample A than the others.

As reported by Albertsson et al. (2013) and ArredondoTorres et al. (2006), a slag with high basicity is interested by spinel solid solution ( $\left.(\mathrm{Mg}, \mathrm{Ca}) \mathrm{Cr}_{2} \mathrm{O}_{3}\right)$ precipitation from the matrix with high amount of impurities and irregular structure and morphology. This seems attributable by the presence of $\mathrm{Cr}^{6+}$ that induces spinel instability. $\mathrm{Cr}^{6+}$ formation is favoured in high basicity slag, since they should have high fraction of not combined $\mathrm{CaO}$ that could react with $\mathrm{Cr}$ to yield $\mathrm{Cr}^{6+}$ (Lee and Nassaralla, 1998). Spinel instability due to high basicity (and thus high $\mathrm{Cr}^{6+} / \mathrm{Cr}^{3+}$ ratio) has been proved to induce high $\mathrm{Cr}$ leaching during standard leaching test (Mombelli et al., 2016). In addition, the low $\mathrm{Al}_{2} \mathrm{O}_{3}$ content in the spinel analyzed in the sample $\mathrm{B} 1$ and $\mathrm{B} 2$ contributes to reduce its stability, thus leading to significant $\mathrm{Cr}$ leaches. These aspects have two consequences: even if the chromium is mainly bound in spinel form, the chromium leaching still occurs, and then, the excess of $\mathrm{Cr}$ decreases the solubility of $\mathrm{V}$ into the spinel phase, favouring its mobility and thus the leachability of such an element (Fig. 9).

\subsection{Leaching test at different $\mathrm{L} / \mathrm{S}$ ratio}

The set of elution tests indicated that at a standard L/S $=10 \mathrm{l} / \mathrm{kg}$ the interaction between water and slag is minimal and the releasing behaviour is mainly governed by the high surfaceto-volume ratio of the powder. The weight loss was very low and only in few cases overcame $1 \%$ even if the high powder surface-on-volume ratio should enhance the kinetic reactions and dissolution rate. This result implies that only a few portions of the material interacts with water and thus, the identification of the dissolved phases during the leaching test (by XRD or SEM) is difficult. Only by increasing the liquid-on-solid ratio is the dissolution of a greater amount of slag possible. Nevertheless, slag dissolution is strictly related to microstructural features and crystallographic phase 


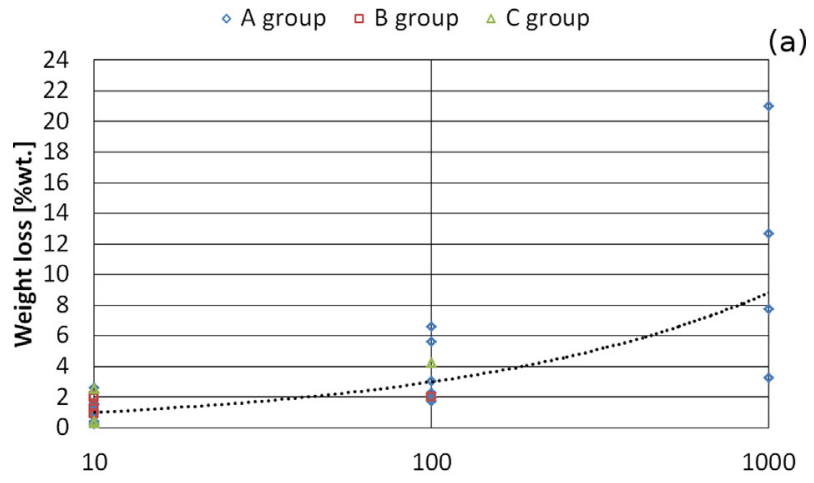

(b)

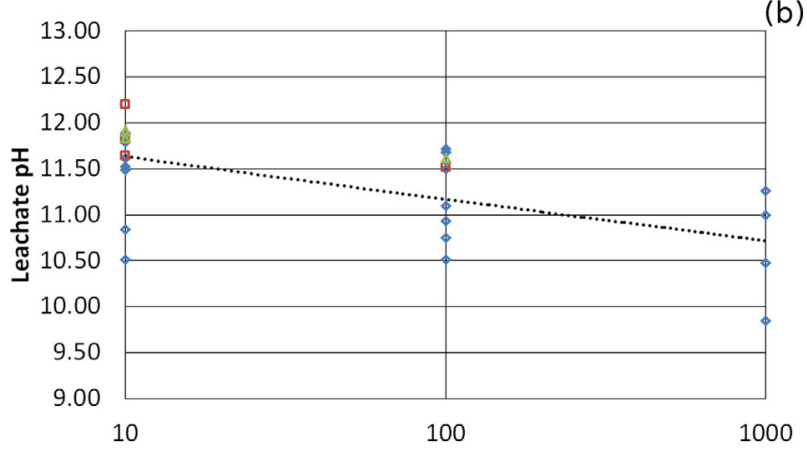

(c)

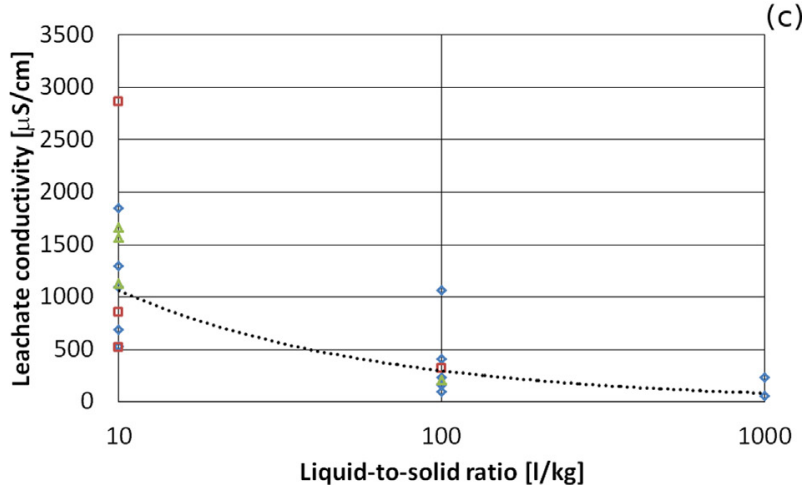

Fig. 10 - Effect of L/S ratio on slag weight loss (a), leachate pH (b) and leachate conductivity (c).

distribution, since not all the structural constituents have the same reactivity with water (Engström et al., 2013; Strandkvist et al., 2015).

The effects of the liquid/solid ratio were quite evident for all of the investigated samples: increasing the water volume caused a corresponding increase in the amount of dissolved slag (Fig. 10a). By increasing the L/S ratio, the leachate $\mathrm{pH}$ decreased (Fig. 10b), as well as the leachate conductivity (Fig. 10c). With the water being less caustic at a high liquid-tosolid ratio, compared to the standard condition, the release of dangerous chemical species could be potentially heightened as the environmental conditions remain away from saturation limits (Mombelli et al., 2014; Nicoleau et al., 2013).

To identify which phases are involved in the hydration/dissolution process, and thus leading to the pollutants release, elution tests on powdered samples at different liquidon-solid ratio were carried out. As described in Fig. 10a, only at a high L/S ratio slag mass is significantly dissolved. For this reason, at $10 \mathrm{l} / \mathrm{kg}$, it is quite impossible to detect any variations in the XRD pattern. Fig. 10 shows the results of XRD analysis performed after the elution test at different $\mathrm{L} / \mathrm{S}$ on several slag samples. In order to compare the different spectra, normalization on the more intense wustite peak is performed. Wustite is selected because it should not react with water; in other words its dissolution rate is so low that it can be considered insoluble (Belhadj et al., 2012). The XRD patterns in Fig. 11 demonstrate the phases involved in the leaching process, confirming the results discussed in the previous paragraphs. The different XRD spectrums resolve that, using a standard L/S ratio $(101 / \mathrm{kg})$, the interaction between slag and water is only cortical and interests a limited portion of material. Larnite and brownmillerite peaks decreased their intensity at high L/S ratios (Fig. $11 \mathrm{~b}$ and d). In addition, Fig. 11b showed the alteration of Ca-chromite, demonstrating the implication of such a phase in the $\mathrm{Cr}$ leaching, previously discussed by Mombelli et al. (2016) on the basis of slag basicity. This structural constituent probably contributes to the uncommon chromium concentration in the leachate, because the reaction between $\mathrm{CaO}$ and $\mathrm{Cr}$ oxide fixes the $\mathrm{Cr}$ status to hexavalent form. In alkaline circumstances and in the presence of atmospheric oxygen $\mathrm{CaCr}_{2} \mathrm{O}_{4}$ can easily be oxidized to $\mathrm{CaCrO}_{4}$, a compound that easily leaches chromium and builds hexavalent chromium from divalent or trivalent chromium (Meegoda et al., 2008; Schwandt and Fray, 2006; Ylipekkala, 2005). The high value of $\mathrm{CaCrO}_{4}$ solubility constant indicates the high solubility of this compound (Selected Solubility, 1997). Also the spinel peaks did undergo intensity reduction, even if the variation is less evident. However, the same analysis highlighted the stability of gehlenite and kirschsteinite, even at a high liquid-to-solid ratio. Thus, these phases can be classified as preferred crystalline phases, able to ensure high microstructural stability (Fig. 10a and d). These results comply and validate those presented by the same author (Mombelli et al., 2014).

Among the different elution test trials, only weak intensity peaks related to the formation of typical hydrated phases

Table 4 - SEM-EDS chemical composition of the phases indicated in Fig. 12 (at.\%).

\begin{tabular}{|c|c|c|c|c|c|c|c|c|c|c|c|c|}
\hline at.\% & $\mathrm{Mg}$ & $\mathrm{Al}$ & $\mathrm{Si}$ & $P$ & $\mathrm{~s}$ & $\mathrm{Ca}$ & $\mathrm{Ti}$ & V & $\mathrm{Cr}$ & $\mathrm{Mn}$ & $\mathrm{Fe}$ & $\mathrm{Ba}$ \\
\hline \multicolumn{13}{|c|}{ Before leaching test } \\
\hline General & 7.36 & 6.78 & 18.81 & 0.11 & 0.15 & 17.92 & 0.29 & 0.11 & 3.98 & 5.45 & 38.98 & 0.06 \\
\hline W & 7.94 & & & & & & & 0.06 & 1.00 & 9.26 & 81.72 & 0.02 \\
\hline $\mathrm{K}$ & 10.50 & & 40.69 & & & 35.66 & & & & 3.20 & 9.95 & \\
\hline $\mathrm{Sp}$ & 8.84 & 16.29 & & & & 0.40 & & 0.21 & 41.83 & 5.01 & 27.31 & 0.11 \\
\hline G & 3.40 & 23.10 & 29.95 & & & 38.78 & & & & 0.72 & 4.05 & \\
\hline \multicolumn{13}{|c|}{ After leaching test } \\
\hline General & 8.09 & 7.67 & 18.52 & 0.17 & 0.30 & 18.01 & & 0.15 & 3.98 & 4.86 & 38.14 & 0.11 \\
\hline W & 10.28 & & & & & & & & 1.01 & 9.01 & 79.63 & 0.07 \\
\hline $\mathrm{K}$ & 12.70 & & 43.59 & & & 33.62 & & & & 2.42 & 7.67 & \\
\hline $\mathrm{Sp}$ & 11.03 & 24.50 & & & & 2.34 & & & 33.00 & 4.01 & 25.12 & \\
\hline G & 4.32 & 23.99 & 28.86 & & & 31.33 & & & & 1.52 & 9.96 & 0.02 \\
\hline
\end{tabular}




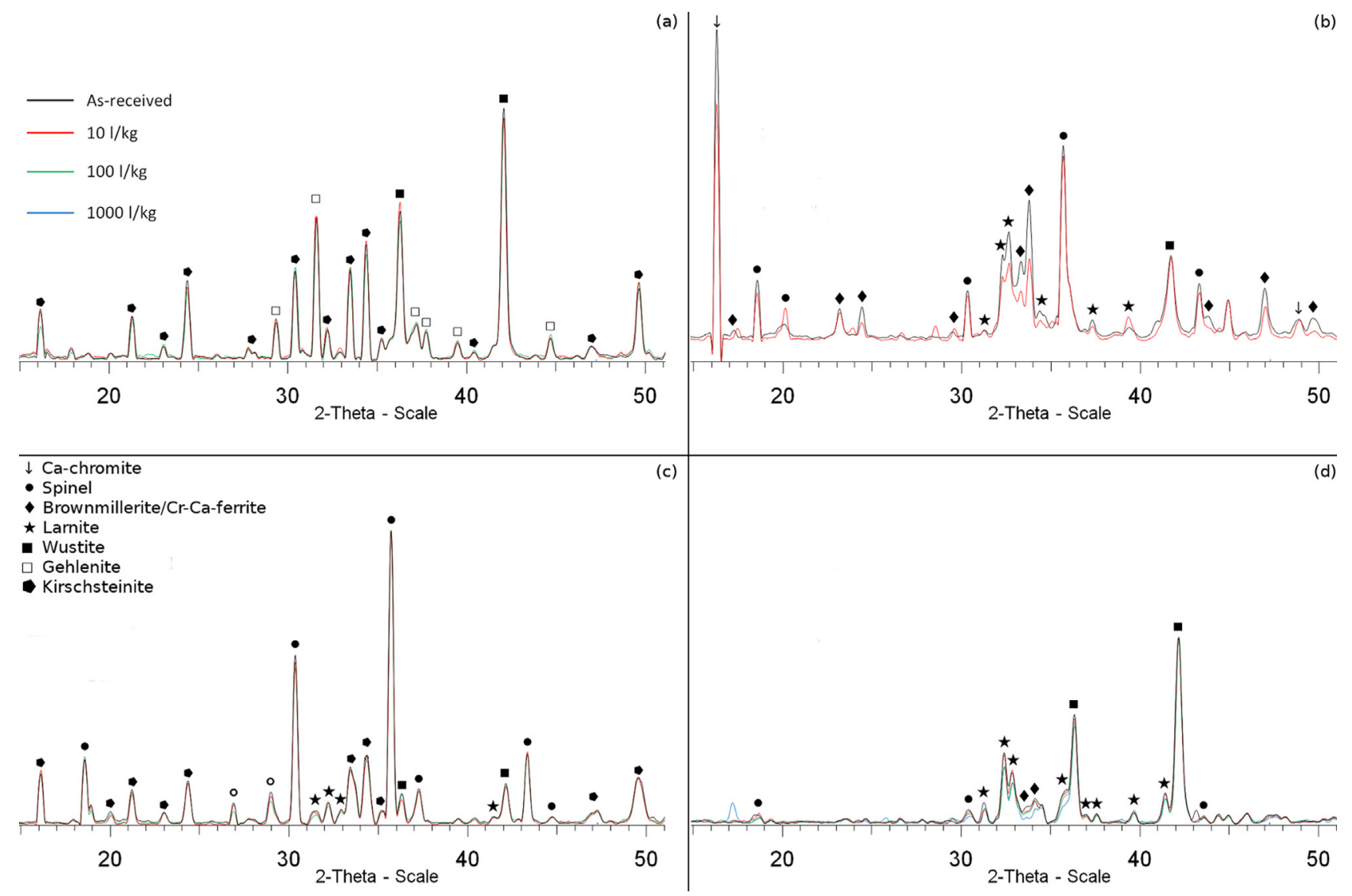

Fig. 11 - XRD patterns at different L/S ratio of slag with stable (a, c) and unstable (b, d) microstructure.
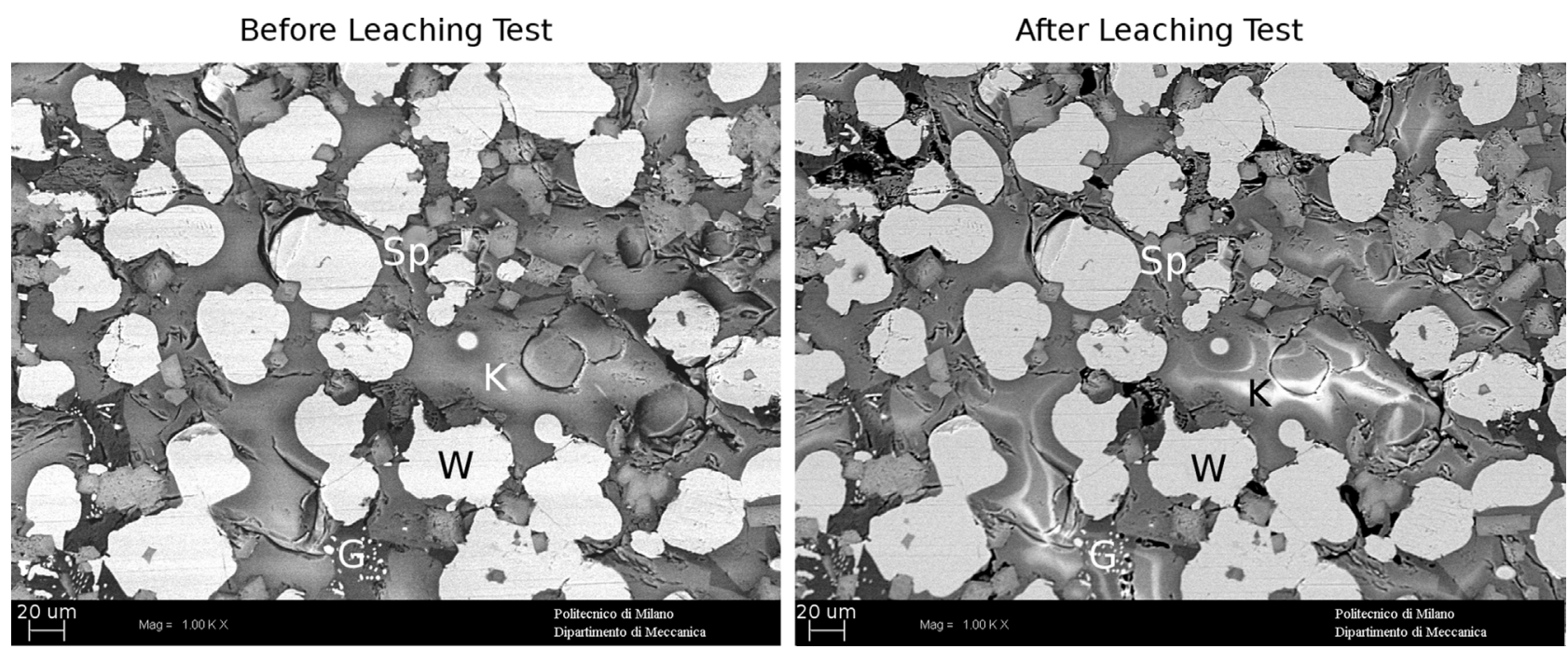

Fig. 12 - SEM-BSE micrographies of polished section before and after leaching test.

(portlandite, calcium silicate hydrate, etc.) were emphasized. Only for the $C$ group samples the high free lime fraction allows a clear identification of portlandite peaks after the leaching test performed on the slag powder.

In order to confirm the non-hydraulic behaviour of the above mentioned phases (gehlenite, kirschsteinite), an elution test with extreme $\mathrm{L} / \mathrm{S}$ ratios was performed on several samples characterized by gehlenite-kirschsteinite matrix. SEM-BSE micrographies did not show any differences before and after the test (Fig. 12). The slag structure appears unaltered and the chemical composition of the phases measured by the EDS probe showed a negligible calcium and iron dissolution (Table 4).
These results highlight the important role of crystalline phases in slag leaching, as previously stated by several authors (Chaurand et al., 2007; van Zomeren et al., 2011; Manso et al., 2005; Geiseler, 1996; Mombelli et al., 2014; Gelfi et al., 2010; Engström et al., 2014; Baciocchi et al., 2015; Costa et al., 2015). While the microstructure is strictly related to the slag chemical composition, a prediction on the leaching attitude of the slag can be evaluated by coupling chemical information, $\mathrm{CaO}-\mathrm{SiO}_{2}-\mathrm{FeO}_{\mathrm{x}}$ and $\mathrm{CaO}-\mathrm{SiO}_{2}-\mathrm{Al}_{2} \mathrm{O}_{3}$ ternary diagrams. In fact, ternary diagrams provide reliable indications about the crystalline phase/phases in the slag matrix, as established by Mombelli et al. (2016). The dangerous metals involved in the leaching process from EAF carbon steel slag are controlled 
by specific crystalline phases (i.e. larnite, brownmillerite, etc.) formed in the slag as a consequence of its chemical composition and cooling method.

\section{Conclusions}

In this work the effects of crystalline phases on slag leaching behaviour were investigated, allowing for the definition of the leaching mechanisms involved in the release of polluting elements. The analysis of fine particles allows for a clarification of the effect of fine fraction on leaching and to identify what phases are involved in the dissolution process. Liquid-on-solid ratio plays a key role on slag leaching behaviour: an increase in L/S can lead to higher slag dissolution and a higher release of pollutants than in standard conditions. Thus, the characterization of the slag leaching behaviour through standard leaching tests alone could be misleading in order to assess the safety of this by-product. In fact, if slag is used as unbound stone material, the continuous wetting-drying cycles may lead to continuous dangerous substances leaching due to layerby-layer dissolution. This consideration suggests characterize slag not only by standard elution test but also with a modified procedure considering the effect of liquid-on-solid ratio. Similarly, the fine particle content can significantly modify the environmental conditions, increasing the leaching rate, even if the slag were declared safe after standard tests. This suggests setting-up leaching tests with different particle sizes.

Mineralogical phases in the slag microstructure strongly influence the slag leaching. Larnite (and its polymorphism) are the phases mainly dissolved during elution tests (in standard conditions) and are responsible for $\mathrm{Ba}$ and $\mathrm{V}$ releasing, also controlling the leachate properties ( $\mathrm{pH}$ and conductivity). Brownmillerite has less solubility than larnite but contributes to an increase in $\mathrm{Ba}$ and $\mathrm{Cr}$ content in eluted water. Chromitelike phases, and not stoichiometric Mg-Cr-spinel, control the chromium dissolution.

High stable phases, like gehlenite and kirschsteinite, seem to improve the slag resistance against dissolution, also at high $\mathrm{L} / \mathrm{S}$ ratio, and these are thus the structural constituents to be favoured in order to produce safe and environmentally friendly slag. Even with different characteristics, in all the investigated slag groups, high gehlenite fraction is associated with better behaviour against pollutant leaching, producing a less caustic and conductive leachate. Thus, gehlenite development is the goal to be achieved in order to enhance the recycling of carbon steel slag as artificial aggregates for bound and unbound applications. The industrial processes developed to stabilize/inertize the EAF slag confirmed this statement. In fact, they are designed to foster the formation of a gehlenite matrix after slag cooling by adding silica or other additives to the molten slag (Patent, 2012, 2014).

\section{Acknowledgment}

The authors would like to acknowledge Thierry Vincent (École des mines d'Alès, C2MA, Alès, France) for the ICP-OES analyses.

\section{References}

Albertsson, G.J., Teng, L., Engstrom, F., Seetharaman, S., 2013. Effect of the heat treatment on the chromium partition in $\mathrm{CaO}-\mathrm{MgO}-\mathrm{SiO}_{2}-\mathrm{Cr}_{2} \mathrm{O}_{3}$ synthetic slags. Metal. Mater. Trans. B 44B, 1586-1597.
Albertsson, G.J., Engstrom, F., Teng, L., 2014. Effect of the heat treatment on the chromium partition in $\mathrm{Cr}$-containing industrial and synthetic slags. Steel Res. Int. 85 (10), 1418-1431.

Arredondo-Torres, V., Romero-Serrano, A., Zeifert, B., Cruz-Rivera, J., Flores-Sanchez, P., Cruz-Ramirez, A., 2006. Stabilization of $\mathrm{MgCr}_{2} \mathrm{O}_{4}$ spinel in slag of the $\mathrm{SiO}_{2}-\mathrm{CaO}-\mathrm{MgO}-\mathrm{Cr}_{2} \mathrm{O}_{3}$ system. Rev. Metal. 42 (6), 417-424.

Baciocchi, R., Costa, G., Polettini, A., Pomi, R., 2015. Effects of thin-film accelerated carbonation on steel slag leaching. J. Hazard. Mater. 286, 369-378.

Barella, S., Gruttadauria, A., Magni, F., Mapelli, C., Mombelli, D., 2012. Survey about safe and reliable use of EAF slag. ISIJ Int. 52 (12), 2295-2302.

Belhadj, E., Diliberto, C., Lecomte, A., 2012. Characterization and activation of basic oxygen furnace slag. Cem. Concr. Compos. $34,34-40$.

Bensted, J., 2002. Calcium aluminates cements. In: Bensted, J., Barnes, P. (Eds.), Structure and Performance of Cements. , 2nd ed. E\&FN Spon, London \& New York.

Cabrera-Real, H., Romero-Serrano, A., Zeifert, B., Hernandez-Ramirez, A., Hallen-Lopez, M., Cruz-Ramirez, A., 2012. Effect of $\mathrm{MgO}$ and $\mathrm{CaO} / \mathrm{SiO}_{2}$ on the immobilization of chromium in synthetic slags. J. Mater. Cycles Waste Manag. 14, 317-324.

Chaurand, P., Rose, J., Briois, V., Olivi, L., Hazemann, J.-L., Domas, J., Bottero, J.-Y., Proux, O., 2007. Environmental impacts of steel slag reused in road construction: a crystallographic and molecular (XANES) approach. J. Hazard. Mater. 139, 537-542.

Costa, G., Polettini, A., Pomi, R., Stramazzo, A., 2015. Leaching modelling of slurry-phase carbonated steel slag. J. Hazard. Mater., http://dx.doi.org/10.1016/j.jhazmat.2015.10.005.

Danieli \& C. Officine Meccaniche S.p.A., 2014. Apparatus and Method for Processing Metallurgic Slag. Patent no. WO2014041418 A3.

De Windt, L., Chaurand, P., Rose, J., 2011. Kinetics of steel slag leaching: batch tests and modeling. Waste Manag. 31, 225-235.

de Wolff, P.M., Visser, J.W., 1988. Absolute Intensities-Outline of a Recommended Procedure. TPD Technical Report 641-109, Reprinted Powder Diffusion., pp. 202-204.

Durink, D., (Ph.D. thesis) 2008. High Temperature Processing of Metallurgical Slags: A Method to Promote Recycling. Department of Materials Engineering, Chemical and Extractive Metallurgy Section, Katholieke Universiteit Leuven, Leuven, Belgium.

Engelsen, C.J., van der Sloot, H.A., Wibetoe, G., Justnes, H., Lund, W., Stoltenberg-Hansson, E., 2010. Leaching characterisation and geochemical modelling of minor and trace elements released from recycled concrete aggregates. Cem. Concr. Res. 40, 1639-1649.

Engelsen, C.J., Wibetoe, G., van der Sloot, H.A., Lund, W., Petkovic, G., 2012. Field site leaching from recycled concrete aggregates applied as sub-base material in road construction. Sci. Total Environ. 427-428, 86-97.

Engström, F., Adolfsson, D., Samuelsson, C., Sandstrom, A., Björkman, B., 2013. A study of the solubility of pure slag minerals. Miner. Eng. 41, 46-52.

Engström, F., Larsson, M.L., Samuelsson, C., Sandström, A., Robinson, R., Björkman, B., 2014. Leaching behavior of aged steel slags. Steel Res. Int. 85 (4), 607-615.

Faellman, A.M., 2000. Leaching of chromium and barium from steel slag in laboratory and field tests - a solubility controlled process? Waste Manag. 20, 149-154.

Faellman, A.M., Hartlén, J., 1996. Utilisation of electric arc furnace slag in road construction. In: Kamon, M. (Ed.), Environmental Geotechnics. Balkema, Rotterdam, pp. 703-708.

Feralpi Siderurgica S.p.A., 2012. Method and Plant for Treating Metallurgical Slag. Patent no. WO2012032379 A1.

Gartner, E.M., Young, J.F., Damidot, D., Jawed, I., 2002. Hydration of portland cement. In: Bensted, J., Barnes, P., et al. (Eds.), Structure and Performance of Cements. E\&FN Spon, London \& New York, pp. 57-114 (Chapter 3). 
Geiseler, J., 1996. Use of steelworks slag in Europe. Waste Manag. 16 (1), 59-63.

Gelfi, M., Cornacchia, G., Roberti, R., 2010. Investigations on leaching behavior of EAF steel slags. In: 6th European Slag Conference (EUROSLAG 2010), Madrid, Spain.

Hewlett, P.C., 1998. Lea's Chemistry of Cement and Concrete, 4th ed. Arnold, pp. 160

Huijgen, W.J.J., Witkamp, G.-J., Comans, R.N.J., 2006. Mechanisms of aqueous wollastonite carbonation as a possible $\mathrm{CO}_{2}$ sequestration process. Chem. Eng. Sci. 61, 4242-4251.

Juckes, L.M., 2003. The volume stability of modern steelmaking slags. Miner. Process. Extr. Metall. 112 (3), 177-197.

Klemm, W.A., Skalny, J., 1977. Selective Dissolution of Clinker Minerals and Its Applications. Martin Marietta Technical Report 77., pp. 26.

Kühn, M., Mudersbach, D., Baena Liberato, J.M., De Angelis, V., Capodilupo, D., De Fries, U., 2006. Chrome Immobilization in EAF Slag from High Alloy Steelmaking - Development of a Slag Treatment Process, Project 7215-PP/044. Office for Official Publications of the European Communities, Luxembourg.

Lea, F.M., 1970. High-Alumina Cement, the Chemistry of Cement and Concrete, 3rd ed. Edward Arnold (Publishers) Ltd., Great Britain, pp. 490-527 (Chapter 16).

Lee, Y., Nassaralla, C.L., 1998. Formation of hexavalent chromium by reaction between slag and magnesite-chrome refractory. Metall. Mater. Trans. B 29B, 405-410.

Liao, C., Tang, Y., Liu, C., Shih, K., Li, F., 2016. Double-barrier mechanism for chromium immobilization: a quantitative study of crystallization and leachability. J. Hazard. Mater. 311, 246-253.

Lind, B.B., Faellman, A.M., Larsson, L.B., 2001. Environmental impact of ferrochrome slag in road construction. Waste Manag. 21, 255-264.

Luxan, M.P., Sotolongo, R., Dorrego, F., Herrero, E., 2000. Characteristics of the slags produced in the fusion of scrap steel by electric arc furnace. Cem. Concr. Res. 30 (4), 517-519.

Manso, J.M., Losanez, M., Polanco, J.A., Gonzalez, J.J., 2005. Ladle furnace slag in construction. J. Mater. Civ. Eng. 17 (5), 513-518.

Meegoda, J.N., Kamolpornwijit, W., Hu, Z., Mueller, R., Patraj, R., 2008. Conversion of chromium ore processing residue to chrome steel. In: Proceedings of Geocongress 2008: Geotechnics of Waste Management and Remediation, ASCE, Geo Institute, Reston, VI, pp. 383-390.

Mizutani, S., Watanabe, N., Sakai, S., Takatsuki, H., 2006. Influence of particle size preparation of MSW incineration residues on heavy metal leaching behavior in leaching tests Environ. Sci. 13 (6), 363-370.

Mombelli, D., Mapelli, C., Barella, S., Di Cecca, C., Le Saout, G., Garcia-Diaz, E., 2016. The effect of chemical composition on the leaching behaviour of electric arc furnace (EAF) carbon steel slag during a standard leaching test. J. Environ. Chem. Eng. 4, 1050-1060.

Mombelli, D., Mapelli, C., Barella, S., Gruttadauria, A., Le Saout, G., Garcia-Diaz, E., 2014. The efficiency of quartz addition on electric arc furnace (EAF) carbon steel slag stability. J. Hazard. Mater. 279, 586-596.

Mombelli, D., Mapelli, C., Gruttadauria, A., Baldizzone, C., Magni, F., Levrangi, P.L., Simone, P., 2012. Analisys of electric arc furnace slag. Steel Res. Int. 83 (11), 1012-1019.

Moser, H., Römbke, J., 2009. Ecotoxicological Characterization of Waste: Results and Experiences of an International Ring. Springer Science \& Business Media, New York, NY.

Mudersbach, D., Kühn, M., Geiseler, J., Koch, K., 2009. Chrome immobilisation in EAF-slags from high-alloy steelmaking: tests at FEhS-Institute and Development of an Operational Slag Treatment Process. In: Proceedings of the 1st Interntational Slag Valorisation Symposium, Leuven, Belgium, April 6-7, 2009, pp. 101-110.
Nicolae, M., Vilciu, I., Zaman, F., 2007. X-ray diffraction analysis of steel slag and blast furnace slag viewing their use for road construction. UPB Sci. Bull. Ser. B 69 (2), 99-108.

Nicoleau, L., Nonat, A., Perrey, D., 2013. The di- and tri-calcium silicate dissolutions. Cem. Concr. Res. 47, 14-30.

Qian, G.R., Sun, D.D., Tay, J.H., Lai, Z., Xu, G., 2002a. Autoclave properties of kirschsteinite-based steel slag. Cem. Concr. Res. 32 (9), 1377-1382.

Qian, G.R., Sun, D.D., Tay, J.H., Lai, Z., 2002b. Hydrothermal reaction and autoclave stability of $\mathrm{Mg}$ bearing $\mathrm{RO}$ phase in steel slag. Br. Ceram. Trans. 101 (4), 159-164.

Raab, B., Stöber, S., Pöllmann, H., 2008. Investigations of the hydration behaviour of pure cement phases by different synthesis methods. In: Fentiman, C.H., Mangabhai, R.J., Scrivener, K.L. (Eds.), Proceedings of the Centenary Conference. Avignon, France, pp. 79-92.

Reddy, A.S., Pradhan, R.K., Chandra, S., 2006. Utilization of basic oxygen furnace (BOF) slag in the production of a hydraulic cement binder. Int. J. Miner. Process. 79 (2), 98-105.

Ruiz-Agudo, E., Putnis, C.V., Rodriguez-Navarro, C., Putnis, A., 2012. Mechanism of leached layer formation during chemical weathering of silicate minerals. Geology 40 (10), 947-950.

Schwandt, C., Fray, D.J., 2006. The electrochemical reduction of chromium sesquioxide in molten calcium chloride under cathodic potential control. In: Proceeding of Conference on Molten Salts and Ionic Liquids (EUCHEM), Hammamet, Tunisia, pp. 655-670.

Selected Solubility Products and Formation Constants, at $25^{\circ} \mathrm{C}$. Available from http://chemistry.csudh.edu/oliver/ chemdata/data-ksp.htmi (last updated 1997).

Shen, H., Forssberg, E., Nordstrom, U., 2004. Physicochemical and mineralogical properties of stainless steel slags oriented to metal recovery. Resour. Conserv. Recycl. 40 (3), 245-271.

Shi, C., 2004. Steel slag - its production, processing, characteristics, and cementitious properties. J. Mater. Civ. Eng. 16 (3), 230-236.

Strandkvist, I., Björkman, B., Engström, F., 2015. Synthesis and dissolution of slag minerals - a study of $\beta$-dicalcium silicate, pseudowollastonite and monticellite. Can. Metall. Q. 54 (4), 446-454.

Taylor, H.F.W., 1990. Cement Chemistry. Academic Press, pp. 10.

Tossavainen, M., Engstrom, F., Yang, Q., Menad, N., Lidstrom Larsson, M., Bjorkman, B., 2007. Characteristics of steel slag under different cooling conditions. Waste Manag. 27, 1335-1344.

Tsakiridis, P.E., Papadimitriou, G.D., Tsivilis, S., Koroneos, C., 2008. Utilization of steel slag for Portland cement clinker production. J. Hazard. Mater. 152 (2), 805-811.

U-Mate Report, 2012. Effect of pH on Heavy Metal Concentration, Process Potential Study. U-Mate International Inc., Valley, AZ, Available from http://humate.com/applications/ environment/.

van Zomeren, A., van der Laan, S.R., Kobesen, H.B.A., Huijgen, W.J.J., Comans, R.N.J., 2011. Changes in mineralogical and leaching properties of converter steel slag resulting from accelerated carbonation at low $\mathrm{CO}_{2}$ pressure. Waste Manag. 31, 2236-2244.

Vítková, M., Ettler, V., Mihaljevic, M., Sebek, O., 2011. Effect of sample preparation on contaminant leaching from copper smelting slag. J. Hazard. Mater. 197, 417-423.

Wachsmuth, F., Geiseler, J., Fix, W., Koch, K., Schwerdtfeger, K., 1981. Contribution to the structure of BOF-slags and its influence on their volume stability. Can. Metall. Q. 20 (3), 279-284.

Ylipekkala, J., (Master thesis) 2005. Quality Management of Chromium Containing Steel Slags from Melt Phase to Cooling. Department of Chemical Engineering and Geosciences, Division of Process Metallurgy, Luleå University of Technology, Luleå, Sweden. 